\title{
De one-tier board volgens de herziene Corporate Governance Code
}

\author{
Mr. T. Salemink*
}

\begin{abstract}
De Corporate Governance Code 2008 is toegeschreven op vennootschappen met een two-tier board (dualistisch bestuurssysteem). Het biedt vennootschappen met een onetier board (monistisch bestuurssysteem) volgens de Monitoring Commissie onvoldoende handvatten en behoeft om die reden herziening. Het is de vraag of de Commissie met de recente herziening van de Code voldoende in haar voornemen tot verduidelijking is geslaagd.
\end{abstract}

\section{Inleiding}

Sinds 1 januari 2013 kent het Nederlandse vennootschapsrecht met artikel 2:129a/239a van het Burgerlijk Wetboek (BW) een wettelijke grondslag voor de invoering van een onetier board (monistisch bestuurssysteem). Bij een vennootschap met een one-tier board zijn bestuur en toezicht ondergebracht in één orgaan met uitvoerende bestuurders en niet-uitvoerende bestuurders.

De Corporate Governance Code (hierna: de Code) uit 2008 is toegeschreven op vennootschappen met een two-tier board (dualistisch bestuurssysteem), waarbij bestuur en toezicht zijn verdeeld over twee afzonderlijke organen.

De Code 2008 biedt vennootschappen met een one-tier board volgens de Monitoring Commissie Corporate Governance Code (hierna: de Commissie) onvoldoende handvatten en behoeft om die reden herziening. De Commissie heeft hiertoe op 3 augustus 2016 een consultatiedocument 'Voorstel toepasbaarheid Code op one tier boards' (hierna: het Voorstel) gepubliceerd. Op 8 december 2016 heeft de Commissie de definitieve herziene Code uitgebracht. Het is de vraag of de Commissie in haar voornemen tot verduidelijking is geslaagd.

In deze bijdrage onderzoek ik de inrichting en het functioneren van een one-tier board volgens de herziene Code. Ik bespreek allereerst het wettelijk kader voor de one-tier board (par. 2) en behandel vervolgens de voor de one-tier board relevante bepalingen uit de herziene Code (par. 3).

\footnotetext{
Mr. T. Salemink is advocaat bij Lemstra Van der Korst in Amsterdam en onderzoeker bij het Van der Heijden Instituut, onderdeel van het Onderzoekcentrum Onderneming \& Recht, van de Radboud Universiteit in Nijmegen. Dit artikel is op persoonlijke titel geschreven.
}

\section{Wettelijk kader one-tier board}

\subsection{Wettelijke grondslag}

De wettelijke verankering voor de one-tier board is voor een belangrijk deel vervat in artikel 2:129a/239a BW.

Het instellen van een one-tier board vergt een statutaire basis. De statuten moeten (ten minste) bepalen dat de bestuurstaken zijn verdeeld over één of meer uitvoerende bestuurders en niet-uitvoerende bestuurders. De daadwerkelijke taakverdeling kan zowel bij als krachtens de statuten - in bijvoorbeeld een (bestuurs)besluit of een reglement - worden uitgewerkt. $^{1}$

De wet bevat relatief weinig voorschriften over de taken van en taakverdeling tussen uitvoerende bestuurders en niet-uitvoerende bestuurders. Het eerste lid van artikel 2:129a/239a BW bepaalt dat de taak om toezicht te houden op de taakuitoefening door bestuurders niet door een taakverdeling kan worden ontnomen aan niet-uitvoerende bestuurders. Verder volgt uit hetzelfde lid dat het voorzitterschap van het bestuur, het doen van voordrachten voor benoeming van een bestuurder en het vaststellen van de bezoldiging van uitvoerende bestuurders niet aan een uitvoerende bestuurder kunnen worden toebedeeld.

Uitvoerende bestuurders nemen ingevolge artikel 2:129a/ 239a lid 2 BW niet deel aan de beraadslaging en besluitvorming over het vaststellen van de bezoldiging van uitvoerende bestuurders.

\subsection{Taken uitvoerende bestuurders en niet-uitvoerende bestuurders}

Uitvoerende bestuurders zijn belast met specifiek omschreven taken van bestuur. Het gaat om taken die (meer) uitvoerend van aard zijn, waaronder in het bijzonder taken met betrekking tot de dagelijkse gang van zaken van de vennootschap en de met haar verbonden onderneming. ${ }^{2}$ De aard en omvang van de dagelijkse gang van zaken verschillen per vennootschap.

1. Hierover uitgebreid M. van Olffen, Inrichting van de one tier vennootschap bij of krachtens de statuten, in: M.J. Kroeze e.a., Bestuur en toezicht (Uitgave vanwege het Instituut voor Ondernemingsrecht, deel 67), Deventer: Kluwer 2009, p. 39-40 en R.G.J. Nowak, Rechtsgeldigheid en doorwerking van buitenstatutaire governance-afspraken, WPNR 2014/7014, p. 348 .

2. Kamerstukken II $2008 / 09,31763,6$, p. 15. 


\section{Maandblad \\ Ondernemingsrecht}

Het kan bijvoorbeeld gaan om het financiële beheer, de in- en verkoop of het aansturen van een bepaald bedrijfsonderdeel.

Aan niet-uitvoerende bestuurders zijn geen specifieke (uitvoerende) taken opgedragen, maar zij hebben in beginsel als hoofdtaak het algemeen besturen. ${ }^{3} \mathrm{Zij}$ zijn anders dan commissarissen actief betrokken bij het algemene beleid van de vennootschap en de besluitvorming over de algemene beleidslijnen, zoals het ontwikkelen van de strategie van de vennootschap. ${ }^{4}$

Naast het algemeen bestuur hebben niet-uitvoerende bestuurders de aanvullende taak toezicht te houden op de taakuitoefening door bestuurders. De taak om toezicht te houden verschilt de facto niet van de toezichthoudende taak van de raad van commissarissen in een two-tier board. ${ }^{5}$ Wel bestaat mogelijk een verschil in het tijdstip van toezicht. De gedachte is dat niet-uitvoerende bestuurders als onderdeel van het bestuur eerder over relevante informatie beschikken, om aldus vroegtijdig in het besluitvormingsproces van het bestuur toezicht te kunnen houden en invloed te kunnen uitoefenen. ${ }^{6}$

Dogmatisch wringt het enigszins dat niet-uitvoerende bestuurders toezicht houden op het algemeen bestuur dat mede tot hun takenpakket en verantwoordelijkheid behoort en dat zij mede vorm hebben gegeven. In de praktijk zal de algemene bestuurstaak van niet-uitvoerende bestuurders echter niet identiek zijn aan die van uitvoerende bestuurders: zij verrichten hun werkzaamheden met enige distantie vanuit een positie van iemand die niet met het dagelijkse bestuur belast is en de facto vooral een toezichthoudende taak vervult. ${ }^{7}$

In een one-tier board besturen uitvoerende bestuurders en niet-uitvoerende bestuurders dus gezamenlijk de auto en bepalen zij gezamenlijk de route, waarbij niet-uitvoerende bestuurders in beginsel vooral meekijken en navigeren vanuit de bijrijdersstoel. In een two-tier systeem zitten commissarissen op de

3. Kamerstukken II $2008 / 09,31763$, 3, p. 14. Uit de wet noch de parlementaire geschiedenis volgt wat algemeen besturen precies inhoudt, zie hierover ook M. Lennarts \& J. Roest, Toezicht; benoeming en ontslag, taken en bevoegdheden en aansprakelijkheid van toezichthouders in besloten verhoudingen, in: B. Bier e.a. (red.), Handboek notarieel ondernemingsrecht (Serie vanwege het Van der Heijden Instituut, deel 132-1), Deventer: Wolters Kluwer 2016, p. 123-124.

4. Kamerstukken II 2008/09, 31763, 6, p. 4. Evenzo L. Timmerman, De two tier-commissaris vergeleken met de one tier-niet-uitvoerende bestuurder, in: M.J. Kroeze e.a., Bestuur en toezicht (Uitgave vanwege het Instituut voor Ondernemingsrecht, deel 67), Deventer: Kluwer 2009, p. 26.

5. Kamerstukken II 2008/09, 31763, 6, p. 15. Deze toezichthoudende taak is niet hetzelfde als de taak van collegiaal toezicht, inhoudende dat ieder lid van een collegiaal opererend orgaan erop moet toezien dat ieder ander lid van dat orgaan zijn taak naar behoren vervult. Hierover uitgebreid R.G.J. Nowak, Het voorstel toepasbaarheid Code op one-tier boards, Ondernemingsrecht 2016/113, p. 566.

6. Kamerstukken II 2008/09, 31763, 6, p. 15.

7. Zie over dit verschil tussen uitvoerende bestuurders en niet-uitvoerende bestuurders uitgebreid S.H.M.A. Dumoulin, De positie van niet-uitvoerend bestuurders in het monistisch bestuursmodel, Ondernemingsrecht 2005/91, p. 269. achterbank en houden vanuit daar toezicht op de rijdende bestuurder, die in eerste instantie de route bepaalt.

\subsection{Taakverdeling en besluitvorming}

Het bestuur kan bij of krachtens de statuten zijn taken verdelen, met uitzondering van de in artikel 2:129a/239a lid $1 \mathrm{BW}$ genoemde taken die zijn voorbehouden aan niet-uitvoerende bestuurders.

De vraag rijst of de specifieke toezichthoudende taak moet worden toebedeeld aan niet-uitvoerende bestuurders of dat deze onverdeeld kan blijven en aldus toekomt aan het bestuur als geheel. Hoewel de wet de mogelijkheid toestaat, maakt het onverdeeld laten van de toezichthoudende taak mijns inziens effectief en adequaat toezicht binnen een one-tier board illusoir (zie par. 3.2). ${ }^{8}$

De taken die niet zijn verdeeld, vallen ingevolge artikel 2:9 BW toe aan het gehele bestuur. Een takkverdeling laat onverlet dat het bestuur als geheel - dus zowel de uitvoerende bestuurders als de niet-uitvoerende bestuurders - verantwoordelijk is.

Het derde lid van artikel 2:129a/239 BW biedt de mogelijkheid om bij of krachtens de statuten te bepalen dat één of meer bestuurders rechtsgeldig kunnen besluiten omtrent zaken die tot zijn respectievelijk hun taak behoren. ${ }^{9}$ Een dergelijk besluit wordt toegerekend aan het gehele bestuur, waarvoor alle bestuurders gezamenlijk verantwoordelijk zijn. ${ }^{10} \mathrm{Het}$ beginsel van collegiaal bestuur brengt mijns inziens mee dat het bestuur als geheel te allen tijde bevoegd blijft te besluiten over de gedelegeerde taak of de desbetreffende bestuurder(s) kan 'overrulen'. 11

8. Zie P.J. Dortmond, Enkele reacties bij verschenen bijdragen, Ondernemingsrecht $2013 / 124$, p. 639 , die van mening is dat de wet het toezicht opdraagt aan niet-uitvoerende bestuurders en daarom art. 2:129a lid 3 BW moet worden toegepast, zodat in de statuten bepaald moet worden dat niet-uitvoerende bestuurders tot taak hebben toezicht te houden en dat zij rechtsgeldig over het toezicht houden kunnen besluiten. Anders: A.F. Verdam, Naschrift II bij reactie Prof. mr. P.J. Dortmond, Ondernemingsrecht $2013 / 126$, p. 640 , die stelt dat de bepaling in art. 2:129a lid 1 BW dat het toezicht niet kan worden ontnomen aan niet-uitvoerende bestuurders, onderstreept dat het een wezenlijk onderdeel van hun taak is; het betekent volgens hem evenwel niet dat de wet het toezicht exclusief opdraagt aan de niet-uitvoerende bestuurders. In gelijke zin: Nowak 2016 , p. 566.

9. Niet alle bestuurstaken zijn mijns inziens voor delegatie vatbaar. Het gaat dan voornamelijk om taken die gelet op hun aard tot de werkkring van het gehele bestuur horen, zoals het algemeen beleid, het algemene financiele beleid of de strategie. Evenzo Nowak 2016, p. 568.

10. Kamerstukken II 2008/09, 31763, 3, p. 17.

11. De regeling van art. $2: 129 \mathrm{a} / 239 \mathrm{a}$ lid $3 \mathrm{BW}$ staat enigszins op gespannen voet met het beginsel van collegiaal bestuur. Evenzo Asser/Maeijer, Van Solinge \& Nieuwe Weme 2-II* 2009/417. Zie uitgebreid hierover A.F. Verdam, Van collegiaal bestuur, bestuursbesluiten, aantastbaarheid en delegatie, en het besluit van een bestuurslid onder het nieuwe artikel 2:129a lid 3, Ondernemingsrecht 2013/102, p. 503-510. 


\section{Herziene Code}

\subsection{Inleiding}

De herziene Code bevat in hoofdstuk 5 enkele bepalingen omtrent de one-tier boardstructuur. Het gaat om één principe en vijf best practice bepalingen.

De wijzigingen ten opzichte van de Code 2008 zijn relatief beperkt en minder uitvoerig dan in het Voorstel. De wet biedt vennootschappen relatief veel vrijheid voor de inrichting van de governance binnen een one-tier board (zie par. 2.1). Uit de consultatieronde bleek volgens de Commissie 'dat de tijd nu nog niet rijp is voor verdere invulling. ${ }^{12}$ De reacties zijn voor de Commissie aanleiding geweest om het Voorstel op een aantal punten aan te passen en de voorgestelde guidance niet uit te brengen.

De beperkte wijzigingen staan in contrast met het oorspronkelijke uitgangspunt van de Commissie. De oude Code is toegeschreven op een two-tier bestuurssysteem en bood volgens de Commissie vennootschappen met een one-tier board onvoldoende handvatten. De Commissie was daarom oorspronkelijk voornemens een afzonderlijke Code voor de one-tier board te schrijven. ${ }^{13}$ In het Voorstel is zij hierop teruggekomen en heeft zij getracht de beoogde duidelijkheid voornamelijk te realiseren met een uitgebreide guidance. ${ }^{14}$ Deze guidance heeft zij uiteindelijk evenmin uitgebracht.

De bepalingen uit de herziene Code omtrent de one-tier board behandel ik hierna thematisch (par. 3.2-3.5). Daarnaast besteed ik aandacht aan de in de toelichting bij de herziene Code voorgeschreven overeenkomstige toepassing van de bepalingen voor de raad van commissarissen op niet-uitvoerende bestuurders (par. 3.6).

\subsection{Toezicht niet-uitvoerende bestuurders}

De Commissie heeft het principe omtrent de one-tier bestuursstructuur niet inhoudelijk gewijzigd en slechts in overeenstemming gebracht met de terminologie van de wet in artikel 2:129a/239a BW. ${ }^{15}$ De bepalingen zijn in beginsel voornamelijk gericht op het waarborgen van behoorlijk en onafhankelijk toezicht door niet-uitvoerende bestuurders.

De wet laat de mogelijkheid open dat de taak van toezicht onverdeeld blijft en aan het gehele bestuur toekomt (zie par. 2.2). De Code neemt echter als uitgangspunt dat de toe-

12. Zie Reacties op het voorstel voor herziening van de Nederlandse Corporate Governance Code, Verantwoording van het werk van de Commissie, 8 december 2016, p. 27 (gepubliceerd op www. commissiecorporategovernance.nl/?page $=3768$ ); hierna: Verantwoording.

13. Voorstel voor herziening van 11 februari 2016, p. 25.

14. Voorstel, p. 4. De wijze waarop de taakverdeling binnen een one-tier board in de praktijk plaatsvindt, verschilt te veel en is op onderdelen nog onvoldoende uitgekristalliseerd om een volledig op de one-tier board toegeschreven Code te rechtvaardigden, aldus de Commissie.

15. Principe 5.1 herziene Code. zichthoudende taak - die in een two-tier board bij de raad van commissarissen ligt - is toebedeeld aan niet-uitvoerende bestuurders. ${ }^{16}$

Dit uitgangspunt lijkt mij juist. Toezicht door niet-uitvoerende bestuurders vormt de basis van een goed functionerend one-tier bestuursmodel. Voor adequaat en onafhankelijk toezicht kan deze taak niet onverdeeld blijven. Het is dogmatisch ook niet goed denkbaar dat degenen die belast zijn met (uitvoerende) bestuurstaken, ook mede degenen zijn die toezicht daarop moeten houden. Dit maakt effectief en onafhankelijk toezicht illusoir.

\subsection{Samenstelling bestuur en commissies}

Het bestuur dient ingevolge best practice bepaling 5.1.1 in meerderheid te bestaan uit niet-uitvoerende bestuurders. De onafhankelijkheidsvereisten voor commissarissen uit best practice bepalingen 2.1.7 en 2.1.8 zijn ook van toepassing op niet-uitvoerende bestuurders. ${ }^{17}$

Deze bepaling sluit grotendeels aan bij de best practice bepaling III.8.4 uit de Code 2008. De voorgeschreven meerderheid van niet-uitvoerende bestuurders waarborgt effectief toezicht binnen een one-tier board. Niet-uitvoerende bestuurders hebben als collectief niet de gebruikelijke wettelijke toezichthoudende bevoegdheden van de raad van commissarissen, zoals het goedkeuringsrecht of de bevoegdheid uitvoerende bestuurders te schorsen. De bevoegdheid tot schorsing van uitvoerende bestuurders komt op grond van artikel 2:134/244 lid 1, laatste zin, BW toe aan het bestuur als geheel. ${ }^{18}$ Het goedkeuringsrecht kan ingevolge artikel 2:129/239 lid $3 \mathrm{BW}$ alleen worden toegekend aan een orgaan van de vennootschap. Nietuitvoerende bestuurders als collectief zijn als zodanig geen orgaan. ${ }^{19}$

De best practice bepaling voorkomt dat uitvoerende bestuurders in weerwil van de toezichthoudende niet-uitvoerende bestuurders besluiten binnen het bestuur kunnen doordrukken en zich aldus van het toezicht onttrekken. Niet-uitvoerende bestuurders krijgen als collectief door hun meerderheid een

16. Hierover ook Nowak 2016.

17. Voor de vennootschap met een one-tier board bestuursstructuur wordt met 'bestuurder' in best practice bepaling 2.1.8 onder i bedoeld 'uitvoerend bestuurder', herziene Code, toelichting onder 5.1 .1 (p. 48).

18. De bevoegdheid uitvoerende bestuurders te schorsen kan op grond van art. 2:129a lid 3 BW worden gedelegeerd aan niet-uitvoerende bestuurders. Evenzo Lennarts \& Roest 2016, p. 123.

19. O.m. Kamerstukken II 2008/09, 31763, 3, p. 21 en Kamerstukken II $2008 / 09,31763$, 6, p. 28. Zie Van Olffen 2009, p. 45 en I. Meijer-Wagenaar, De bezoldiging van de uitvoerende bestuurder, de niet-uitvoerende bestuurder en de commissaris bij de naamloze vennootschap: een vennootschapsrechtelijke vergelijking, TvOB 2014, afl. 4, p. 119, die het mogelijk achten dat niet-uitvoerende bestuurders als afzonderlijk orgaan in de zin van art. 2:135 lid $4 \mathrm{BW}$ bevoegd worden verklaard de bezoldiging van uitvoerende bestuurders vast te stellen, omdat het begrip orgaan in art. 2:135 lid $4 \mathrm{BW}$ niet is opgenomen in art. 2:78a BW. 


\section{Maandblad}

Ondernemingsrecht

de-factogoedkeuringsrecht en schorsingsbevoegdheid. ${ }^{20} \mathrm{Wel}$ is noodzakelijk dat niet-uitvoerende bestuurders niet alleen in persoon, maar ook in aantal uit te brengen stemmen de meerderheid vertegenwoordigen.

Ten opzichte van de Code 2008 heeft de Commissie verduidelijkt dat niet alle niet-uitvoerende bestuurders onafhankelijk dienen te zijn in de zin van de Code: maximaal één niet-uitvoerende bestuurder mag afhankelijk zijn. ${ }^{21} \mathrm{Op}$ grond van de oude bepaling leek dit niet mogelijk. ${ }^{22}$ Een tweede verschil is dat meer niet-uitvoerende bestuurders (tezamen minder dan de helft van het totaal antal niet-uitvoerende bestuurders) afhankelijk mogen zijn, in die zin dat $\mathrm{zij}^{23}$ een aandelenpakket van ten minste $10 \%$ in de vennootschap houden en/of functionaris zijn bij een rechtspersoon met een aandelenpakket van ten minste $10 \%$ in de vennootschap. ${ }^{24}$

De onafhankelijkheidsvereisten in best practice bepaling 2.1.7 zijn in beginsel toegeschreven op een two-tier systeem met een afzonderlijk toezichthoudend orgaan. Het voorschrift waarborgt dat de raad van commissarissen altijd in meerderheid uit onafhankelijke leden bestaat.

Dit geldt echter niet zonder meer voor een one-tier board dat slechts één orgaan kent. In een bestuur met bijvoorbeeld twee uitvoerende bestuurders en vijf niet-uitvoerende bestuurders kan in overeenstemming met de Code een meerderheid van vier bestuurders niet onafhankelijk zijn. ${ }^{25}$ Dit levert mogelijk spanning op met het uitgangspunt van onafhankelijk toezicht. In de praktijk zal dit echter vermoedelijk weinig problemen opleveren, omdat de toezichthoudende taak (en de besluitvorming daaromtrent) veelal toebedeeld is aan niet-uitvoerende bestuurders, van wie de meerderheid onafhankelijk dient te zijn, en onafhankelijk toezicht gewaarborgd blijft.

De raad van commissarissen dient ingevolge Principe 2.3 commissies in te stellen om de besluitvorming van de raad voor te bereiden. In een one-tier board geldt hetzelfde voor de besluitvorming van niet-uitvoerende bestuurders. ${ }^{26}$ Hiervoor is wel

20. Hierover ook A.R.J. Croiset van Uchelen, Dichter bij het vuur? Over de aansprakelijkheid van niet-uitvoerende bestuurders, TOP 2014/242, p. 30-31.

21. Best practice bepaling 2.1.7 sub i.

22. Best practice bepaling III.8.4 verklaarde alleen de onafhankelijkheidsvereisten van best practice bepaling III.2.2 van overeenkomstige toepassing op niet-uitvoerende bestuurders, en niet ook best practice bepaling III.2.1. Laatstgenoemde bepaling hield in dat alle commissarissen, met uitzondering van maximaal één persoon, onafhankelijk dienden te zijn in de zin van best practice-bepaling III.2.2.

23. Ofwel zijn echtgenoot, geregistreerde partner of andere levensgezel, pleegkind of bloed- of aanverwant tot in de tweede graad, zie best practice bepaling 2.1.8 aanhef.

24. Best practice bepaling 2.1.7 sub ii jo. best practice bepaling 2.1 .8 sub vi en vii.

25. Vier van de zeven bestuurders kunnen afhankelijk zijn in de zin van de Code: de twee uitvoerende bestuurders en twee van de vijf niet-uitvoerende bestuurders.

26. Zie de 'schakelbepaling' in de toelichting (par. 3.6), maar ook het feit dat best practice bepaling 5.1.4 expliciet refereert aan de commissies van de raad van commissarissen in best practice bepaling 2.3.3. noodzakelijk dat de besluitvorming omtrent de desbetreffende onderwerpen op grond van artikel 2:129a lid $3 \mathrm{BW}$ is toebedeeld aan niet-uitvoerende bestuurders. ${ }^{27}$

Best practice bepaling 5.1.4 bepaalt dat van de auditcommissie, de remuneratiecommissie en de selectie- en benoemingscommissie uitsluitend niet-uitvoerende bestuurders deel uitmaken. Het voorzitterschap van de eerste twee commissies wordt niet vervuld door de voorzitter van het bestuur of door een voormalig uitvoerende bestuurder. Deze bepaling is ongewijzigd overgenomen uit de Code 2008. ${ }^{28}$

In het Voorstel stond dezelfde beperking voor het voorzitterschap van de selectie- en benoemingscommissie. De Commissie heeft deze beperking uiteindelijk niet gehandhaafd omdat uit de consultatiereacties bleek dat de voorzitter (van de raad van commissarissen) juist de aangewezen persoon is om voorzitter van de selectie- en benoemingscommissie te zijn; het behoort tot zijn kerntaken. ${ }^{29}$

Bij een two-tier systeem geldt ingevolge best practice bepaling 2.3.4 dat meer dan de helft van de commissieleden onafhankelijk moet zijn. Voor de one-tier board ontbreekt in best practice bepaling 5.1 .4 een vergelijkbare bepaling. Niettemin geldt dit onafhankelijkheidsvereiste via de 'schakelbepaling' in de toelichting (zie par. 3.6) mijns inziens ook voor een one-tier board.

\subsection{Voorzitter bestuur}

De voorzitter van het bestuur heeft in de Code een belangrijke rol ten aanzien van het waarborgen van adequaat en onafhankelijk toezicht binnen een one-tier board.

Het voorzitterschap kan op grond van artikel 2:129a lid $1 \mathrm{BW}$ niet aan een uitvoerende bestuurder worden toebedeeld. ${ }^{30}$ In aanvulling daarop bepaalt best practice bepaling 5.1.3 dat de voorzitter evenmin uitvoerende bestuurder mag zijn geweest. Deze bepaling is overgenomen uit de Code 2008.31

De Commissie heeft verduidelijkt dat de voorzitter onafhankelijk dient te zijn in de zin van de Code. De Code 2008 ken-

27. Voor de remuneratiecommissie en de selectie- en benoemingscommissie bepaalt art. 2:129a lid $1 \mathrm{BW}$ al dat deze taken niet an uitvoerende bestuurders kunnen worden toebedeeld en dus dat de besluitvorming daaromtrent logischerwijs bij niet-uitvoerende bestuurders ligt.

28. Best practice bepalingen III.8.3, III.5.6 en III.5.11.

29. Verantwoording, p. 14. The UK Corporate Governance Code bepaalt expliciet dat de bestuursvoorzitter ook voorzitter van de selectie- en benoemingscommissie kan zijn (Code Provision B.2.1).

30. In de praktijk bestaan vennootschappen die van dit wettelijke uitgangspunt afwijken, waarbij een niet-uitvoerende bestuurder met de titel Senior Non-Executive Director formeel de voorzitter van het bestuur is, maar een uitvoerende bestuurder feitelijk deze rol vervult. Deze variant waarbij de functies van voorzitter en eerstverantwoordelijke bestuurder (CEO) veelal in één persoon zijn verenigd - is met name gebruikelijk in de Verenigde Staten. Dit model lijkt op gespannen voet te staan met art. 2:129a/239a lid $1 \mathrm{BW}$, aldus ook A.A. Bootsma, De voorzitter van de one-tier board als dwaallicht, Ondernemingsrecht 2016/108.

31. Best practice bepaling III.8.1. 
de dit vereiste niet. ${ }^{32}$ De herziene Code staat toe dat meer niet-uitvoerende bestuurders niet onafhankelijk zijn in de zin van best practice bepaling 2.1.8 sub vi en vii (het aandelenbezit; zie par. 3.3). De Commissie heeft het onafhankelijk toezicht willen waarborgen door voor te schrijven dat in ieder geval de voorzitter geheel onafhankelijk is. ${ }^{33}$

De voorzitter leidt ingevolge best practice bepaling 5.1.2 de vergaderingen van het bestuur. Hij ziet erop toe dat het bestuur als collectief alsmede de commissies van het bestuur evenwichtig zijn samengesteld en naar behoren functioneren. ${ }^{34}$ De Commissie heeft hiermee de taken van de bestuursvoorzitter ten opzichte van de Code 2008 verder uitgewerkt. ${ }^{35}$ Daarnaast geldt de taakomschrijving van de voorzitter van de raad van commissarissen in best practice bepaling 2.3.6 via de 'schakelbepaling' in de toelichting (zie par. 3.6) ook voor de voorzitter van een one-tier board. ${ }^{36}$

In het Voorstel stond dat de voorzitter van het bestuur primair verantwoordelijk was voor leiderschap binnen en effectiviteit van het bestuur en de commissies. De voorgestelde bepaling heeft de Commissie terecht geschrapt omdat de bewoordingen op gespannen voet staan met het uitgangspunt van collectieve verantwoordelijkheid van het bestuur en mogelijk tot een verhoogde aansprakelijkheid van de voorzitter zouden kunnen leiden. ${ }^{37}$

\subsection{Verantwoording toezicht niet-uitvoerende bestuurders}

Nieuw in de herziene Code is best practice bepaling 5.1.5, die voorschrijft dat niet-uitvoerende bestuurders verantwoording afleggen over het uitgeoefende toezicht in het afgelopen boekjaar.

De verantwoording dient in ieder geval te zien op een aantal specifieke best practice bepalingen, zoals de naleving van de onafhankelijkheidsvereisten (2.1.10), de wijze van evaluatie van het bestuur en de individuele bestuurders (2.2.8) en de mate van aanwezigheid van de bestuurders bij de vergaderingen (2.4.4).

De Code laat niet-uitvoerende bestuurders vrij in de wijze waarop zij verantwoording afleggen. $\mathrm{Zij}$ kunnen hiervoor een

32. Hierover Timmerman 2009, p. 25.

33. Dat wil zeggen ten aanzien van alle vereisten ( $\mathrm{sub} \mathrm{i} t / \mathrm{m}$ vii) in best practice bepaling 2.1.8.

34. Deze taakomschrijving sluit aan bij de gedachte dat de bestuursvoorzitter het voorzitterschap van de selectie- en benoemingscommissie tot zijn kerntaken mag rekenen (zie par. 3.3).

35. De eerste zin is nieuw en het tweede gedeelte komt grotendeels overeen met de best practice bepaling III.8.2 uit de Code 2008. Deze bepaling schreef voor dat de voorzitter van het bestuur diende toe te zien op een goede samenstelling en functionering van het gehele bestuur.

36. Herziene Code, toelichting onder 5.1.1 (p. 48). Zie over de taken van de voorzitter van een one-tier board uitgebreid S.R. Schuit, The chairman makes or breaks the board. De rol van de chairman van Nederlandse beursgenoteerde ondernemingen, Amsterdam: Gopher 2010, p. 47-81.

37. Verantwoording, p. 28 afzonderlijk verslag opstellen, maar ook in het bestuursverslag ex artikel 2:391 BW aandacht besteden aan de uitvoering van hun toezichthoudende werkzaamheden. ${ }^{38}$ Ook is het volgens de Commissie denkbaar dat in het bestuursverslag een brief van de voorzitter wordt opgenomen waarin niet-uitvoerende bestuurders verantwoording afleggen. ${ }^{39}$

\subsection{Overeenkomstige toepassing bepalingen commissarissen}

\section{Schakelbepaling (zonder guidance)}

De toelichting bij de herziene Code verklaart de bepalingen die betrekking hebben op commissarissen ook van toepassing op niet-uitvoerende bestuurders, onverminderd de overige verantwoordelijkheden die deze bestuurders hebben. Waar dit niet mogelijk is, geldt het 'pas toe of leg uit'-principe. ${ }^{40}$

Deze schakelbepaling is niet nieuw en overgenomen uit eerder gegeven guidance bij de oude Code. ${ }^{41}$ Dit uitgangspunt staat haaks op de mijns inziens terechte constatering van de Commissie in het Voorstel dat voor een goede toepassing van de Code op vennootschappen met een one-tier board niet kan worden volstaan met een taalkundige exercitie waarbij elke verwijzing naar de 'raad van commissarissen' wordt vervangen door 'niet-uitvoerende bestuurders' en het 'bestuur' door 'uitvoerende bestuurders' ${ }^{42}$

Niet-uitvoerende bestuurders zijn bestuurders en maken deel uit van het bestuur. De taak en verantwoordelijkheid van nietuitvoerende bestuurders zijn dan ook anders en ruimer dan die van commissarissen (zie par. 2.2).

De een-op-eentoepassing van de bepalingen omtrent commissarissen op niet-uitvoerende bestuurders zonder een nadere motivering of guidance kan op onderdelen mogelijk tot onduidelijkheid leiden. Ik bespreek twee voorbeelden: het ontwikkelen van de strategie en de goedkeuring van bestuursbesluiten.

\section{Ontwikkeling strategie}

Het bestuur ontwikkelt op grond van best practice bepaling 1.1.1 een visie op langetermijnwaardecreatie en formuleert een daarbij passende strategie. Best practice bepaling 1.1.2 schrijft voor dat het bestuur de raad van commissarissen tijdig dient te betrekken bij het formuleren van de strategie en dat het aan de

38. Herziene Code, toelichting onder 5.1.5 (p. 49).

39. Voorstel, p. 9.

40. Herziene Code, toelichting onder 5.1 (p. 48).

41. Monitoringrapport boekjaar 2012, p. 12. Volgens de Commissie moet het met betrekking tot het 'pas toe of leg uit'-principe gaan om ondernemingsspecifieke uitleg waarom niet aan de vereisten van de Code kan worden voldaan. Het enkele feit dat sprake is van een one-tier structuur, is volgens de Commissie onvoldoende uitleg en ziet zij als niet-naleving van de Code. Zie Overzicht van eerder gegeven guidance, augustus 2015, p. 8 .

42. Voorstel, p. 4. 


\section{Maandblad}

Ondernemingsrecht

raad van commissarissen verantwoording aflegt over de strategie en de toelichting daarop.

Deze bepalingen zijn niet zonder meer rechtstreeks toepasbaar op een one-tier board. Niet-uitvoerende bestuurders zijn belast met het algemeen bestuur en anders dan commissarissen actief betrokken bij het algemeen beleid, waaronder ook de formulering van de strategie (zie par. 2.2). ${ }^{43}$

Uitvoerende bestuurders dienen niet-uitvoerende bestuurders dan ook niet zozeer te betrekken bij het ontwikkelen van de strategie, maar zij formuleren de strategie gezamenlijk als collectief bestuur. Zowel uitvoerende als niet-uitvoerende bestuurders zijn hiervoor in gelijke zin verantwoordelijk, waardoor de verantwoordingsplicht in best practice bepaling 1.1.2 wringt.

De feitelijke taakverdeling omtrent het formuleren van de strategie zal in de praktijk echter niet wezenlijk verschillen tussen een monistisch en een dualistisch bestuurssysteem. Ook binnen een one-tier board zal het initiatief voor de strategie uitgaan van uitvoerende bestuurders en zullen niet-uitvoerende bestuurders met enige afstand meekijken en -beslissen. Het zal eerder een nuanceverschil zijn dat niet-uitvoerende bestuurders wellicht een actievere bemoeienis hebben dan commissarissen; maar ook dit zal meer van de persoon dan van de functie afhangen.

Het ontbreken van enige guidance bij deze bepaling voor de one-tier board leidt wellicht wel tot onduidelijkheid met betrekking tot de collectieve verantwoordelijkheid en mogelijke aansprakelijkheidsrisico's van niet-uitvoerende bestuurders.

Niet-uitvoerende bestuurders zijn in beginsel gelijk met uitvoerende bestuurders verantwoordelijk (en mogelijk aansprakelijk) voor de gekozen strategie. ${ }^{44}$ Voor commissarissen geldt dit niet zonder meer, althans in mindere mate: zij zijn verantwoordelijk voor het toezicht op het formuleren van de strategie.

Hoewel het verschil in aansprakelijkheidsrisico's tussen nietuitvoerende bestuurders en commissarissen volgens mij in de praktijk minder groot zal zijn, gelet op de disculpatiemogelijkheden van niet-uitvoerende bestuurders met een beroep op de taakverdeling, ${ }^{45}$ is het niettemin wenselijk om het verschil in verantwoordelijkheid te verduidelijken in de Code.

De Commissie kan daarvoor aansluiting zoeken bij Principle A4 uit The UK Governance Code, waarbij de medeverantwoordelijkheid van de non-executives duidelijk(er) tot uiting komt:
'As part of their role as members of a unitary board, nonexecutive directors should constructively challenge and help develop proposals on strategy.'

\section{Goedkeuringsrecht bestuursbesluiten}

De herziene Code bevat op een aantal onderdelen een goedkeuringsrecht voor de raad van commissarissen ten aanzien van bepaalde bestuursbesluiten, zoals de benoeming en het ontslag van de interne auditor en het aangaan van transacties met een tegenstrijdig belang. ${ }^{46}$

De vraag rijst hoe dit goedkeuringsrecht moet worden toegepast binnen een one-tier board. Een goedkeuringsrecht vereist strikt genomen twee organen: het besluit van het ene orgaan dient te worden voorgelegd aan een ander orgaan. Een one-tier board kent slechts één orgaan, waarbij alle bestuurders - zowel uitvoerende als niet-uitvoerende - collectief verantwoordelijk zijn voor de bestuursbesluiten. ${ }^{47}$

In de niet-uitgebrachte guidance suggereert de Commissie aansluiting te zoeken met het mechanisme van artikel 2:164a lid 4 BW. Dit artikel bepaalt dat in het structuurregime belangrijke bestuursbesluiten de 'goedkeuring' behoeven van de meerderheid van niet-uitvoerende bestuurders. ${ }^{48}$ Volgens de Commissie is het ter keuze van de vennootschap of het goedkeurend besluit genomen dient te worden buiten de aanwezigheid van uitvoerende bestuurders. ${ }^{49}$

De Commissie wekt ten onrechte de indruk dat de 'goedkeuring' door niet-uitvoerende bestuurders een afzonderlijk besluit betreft. Dat is het echter niet. Het gaat in feite om één besluit van de gezamenlijke bestuurders, waarvoor in ieder geval de meerderheid van de niet-uitvoerende bestuurders is vereist. $^{50}$

Van Olffen acht het niet zonder meer noodzakelijk dat de besluitvorming door alle bestuurders op hetzelfde moment plaatsvindt. ${ }^{51}$ Doordat niet-uitvoerende bestuurders hetzelfde bestuursbesluit op een later moment dan uitvoerende bestuurders nemen, hebben zij de facto een goedkeuringsrecht. Er

46. Zie voor het goedkeuringsrecht van de raad van commissarissen best practice bepalingen 1.3.1 (benoeming en ontslag interne auditor), 1.3.3 (werkplan interne auditor), 2.3.10 (benoeming en ontslag bestuurssecretaris), 2.4.2 (aanvaarding nevenfuncties), 2.7.2 en 2.7.4-2.7.5 ('tegenstrijdig belang-transacties').

47. Evenzo Kamerstukken II 2008/09, 31763, 3, p. 21 en Kamerstukken II 2008/09, 31763, 6, p. 28.

48. Zie over de parlementaire geschiedenis van het 'goedkeuringsrecht' in art. 2:164a lid 4 BW uitgebreid Nowak 2016, p. 567.

49. Voorstel, p. 8.

50. Evenzo S.H.M.A. Dumoulin, Het monistische bestuursmodel volgens de Wet bestuur en toezicht - observaties vanuit de praktijk, Ondernemingsrecht 2012/90, p. 493, Dortmond 2013, p. 638 en Lennarts \& Roest 2016, p. 122.

51. M. van Olffen, Naschrift I bij reactie Prof. mr. P.J. Dortmond, Ondernemingsrecht 2013/125, p. 640 en M. van Olffen, Consultatie monistisch bestuursmodel coöperatie en onderlinge waarborgmaatschappij, Onder- nemingsrecht 2013/90, p. 452.
43. Evenzo Timmerman 2009, p. 26

44. Evenzo Lennarts \& Roest 2016, p. 136-137.

45. Evenzo Lennarts \& Roest 2016, p. 124-125 en 137. 


\section{Maandblad}

komt geen besluit van het bestuur tot stand zonder de 'goedkeuring' van niet-uitvoerende bestuurders.

Hoewel deze variant mogelijk beter ansluit bij de praktijk, heb ik mijn twijfels over besluitvorming op afzonderlijke momenten. ${ }^{52}$ Niet alleen rijzen aldus vragen over de aard en aantastbaarheid van de verschillende 'besluiten', maar het uitgangspunt van een one-tier board is juist dat toezichthoudende niet-uitvoerende bestuurders in onderling overleg met uitvoerende bestuurders gezamenlijk als collectief bestuur besluiten. ${ }^{53} \mathrm{Er}$ ontstaat feitelijk een one-tier board met two-tier board-uitgangspunten en -kenmerken.

De term 'goedkeuring' en de (suggestie van) afzonderlijke besluiten leiden bovendien mogelijk tot verwarring ten aanzien van de verantwoordelijkheid van en de aansprakelijkheidsrisico's voor de niet-uitvoerende bestuurders (zie hiervoor). Anders dan commissarissen zijn niet-uitvoerende bestuurders medeverantwoordelijk voor de bestuursbesluiten; zij houden niet enkel toezicht daarop.

Het is mijns inziens dan ook wenselijk dat de Code meer toelichting of guidance geeft over de toepassing van het goedkeuringsrecht in een one-tier board.

\section{Conclusie}

De wettelijke verankering van het one-tier bestuursmodel begin 2013 en de toename van het aantal vennootschappen met een monistische bestuursstructuur zijn volgens de Commissie reden om de Code te verduidelijken. De Code uit 2008 is toegeschreven op een two-tier bestuurssysteem en biedt vennootschappen met een one-tier board onvoldoende handvatten.

De Commissie had oorspronkelijk het idee een afzonderlijke Code voor de one-tier board te schrijven, maar is daar uiteindelijk op teruggekomen. Die beslissing is gelet op de beperkte tijd van de Commissie en de complexiteit van het onderwerp begrijpelijk. De huidige herziening van de Code is al omvangrijk en bijzonder ambitieus.

De beoogde verduidelijking kan de Commissie bovendien ook realiseren door middel van aanvullende best practice bepalingen of toelichting voor de specifieke toepassing van de bepalingen omtrent commissarissen op niet-uitvoerende bestuurders.

De Commissie is daar mijns inziens echter onvoldoende in geslaagd. De herziene Code bevat voor de one-tier board niet

52. Evenzo Nowak 2016, p. 567 en Dumoulin 2012, p. 493.

53. Zie in dit verband ook HR 15 juli 1968, NJ 1969/101 (Wijsmuller), waarin de Hoge Raad heeft bepaald dat bij besluitvorming door een meerhoofdig orgaan van een rechtspersoon het besluit tot stand moet komen als vrucht van onderling overleg van alle leden van dat orgaan die, na daartoe in de gelegenheid te zijn gesteld, aan dat overleg wensen deel te nemen. Door het moment van besluitvorming door uitvoerende en nietuitvoerende bestuurders te scheiden komt een besluit mogelijk niet (voldoende) tot stand door middel van onderling overleg. of nauwelijks wijzigingen en (te) weinig verduidelijking ten opzichte van de oude Code. De Commissie beschouwt nietuitvoerende bestuurders te veel als commissarissen en miskent de verschillen in bijvoorbeeld de verantwoordelijkheid en de aansprakelijkheidsrisico's tussen beide functies.

Een afzonderlijke Code voor de one-tier board is (nog) niet noodzakelijk, maar ik had graag gezien dat de Commissie in de herziene Code op een aantal onderdelen meer duidelijkheid had verschaft over de positie van niet-uitvoerende bestuurders. 